up in 1937 to further the interests of the scientific documentary film, to encourage the making and to sponsor the exhibition of such films. The films are broadly of three kinds : interpretative films, which bring out the relations of science to society and which try to smooth out the difficulties arising from developments and changes in science and social life; educational films, aiming simply to instruct; and research films, serving as a scientific instrument in the hands of the research worker. The Scientific Films Committee grades films into classes in this way, and also appraises their scientific value. The Committee's lists can be obtained on application; universities, schools and scientific societies can use them to help in making up programmes of scientific films. The work of appraising films will go on through the summer. In addition, the Committee's advice is available to producers, and recommendations for new films are to be made; certain subjects, such as chemistry, are very inadequately covered. The Committee wants the opinions of teachers and heads of scientific departments on what is needed, and the special requirements of war-time will be borne in mind.

\section{Radiotherapeutic Panel of Physicists}

SINCE the gift of a large sum of money to the King Edward's Hospital Fund by Sir Otto Beit in 1928 for the purchase of radium for use in the treatment of cancer, the Fund has taken an ever-increasing practical interest in the work associated with this and other gifts especially reserved for radium. When the National Radium Commission came into being in 1929, working arrangements were soon made between it and the Fund whereby the latter body became responsible for seeing that the radium needs of the London area were satisfied. In the developments of the last few years, the Fund has been assisted by an expert Radium Committee, which is now presided over by Sir Cuthbert Wallace. Recently this Committee has been considering in what way radiological treatment could be improved, and the Fund has approved the formation of a panel of consultant physicists. The chief reason that has led to this step is the realization that radiotherapy should be, can be, and is at some centres carried out on a quantitative basis, and that for this purpose the services of a physicist are necessary. The panel is designed to serve the needs of the many hospitals in which radium and $\mathrm{X}$-ray treatment is carried out, but at which the employment of a physicist is precluded by expense. The groups of physicists constituting this panol are as follow : Dr. H. T. Flint and colleagues, Physics Department, Westminster Hospital, S.W.1 ; Mr. L. G. Grimmett and colleagues, Physics Department, Radium Beam Therapy Research, Radium Institute, Ridinghouse Street, W.1; Prof. F. L. Hopwood and colleagues, Physics Department, St. Bartholomew's Hospital, E.C.1 ; Dr. W. V. Mayneord and colleagues, Physics Department, Royal Cancer Hospital, Fulham Road, S.W.3 ; Prof. S. Russ and colleagues, Physics Department, Middlesex Hospital, W.1.

\section{African Studies in War-time Paris}

WHILE the intellectual and scientific activities of Paris, like those of London, suffered dislocation at the outbreak of war, efforts have been and continue to be made to resume them in as full a measure as is compatible with the demands of war on the resources of the city. In a review of what has been accomplished so far, with special reference to the facilities for African studies, Prof. Henri Labouret (Africa, 13, 2 ; 1940) refers to the action of the Government in sanctioning the reopening of the Ecole Nationale de la France d'Outremer (École Coloniale). As an adjunct, the public as well as the students have been readmitted to the facilities for reading and study in the libraries and exhibition galleries of the Musée de l'Homme (Trocadéro) and the Institut d'Ethnologie. The Institut Français d'Anthropologie, the Société des Africanistes and the Société d'Anthropologie have resumed work and are to continue their meetings.

In view of the need for the extension of the cooperation of French and British authorities in Africa to the field of scientific research-a need which should be self-evident-it is interesting to note that $M$. Labouret is able to record that the Institut Français d'Afrique Noir, although it has lost a number of its most prominent supporters, has survived the crisis. This body was founded in 1938 only, but is already recognized as an important centre of African research. It will continue to publish its substantial Notes Africaines, and has taken over the responsibility of issuing the Bulletin du Comité d'Etudes Historiques et Scientifiques de l'Afrique Occidentale Française, founded by Prof. M. Delafosse in 1915. It will appear, however, in a new and enlarged form.

\section{Daytime Lighting of Blacked-out Factories}

THE Industrial Health Research Board is at present investigating the effects of complete obscuration of daylight on health and output, and also the problem of securing the best artificial lighting during the hours of daylight. R. Maxted and J. Bertram, who have been associated. with this work, have written an interesting account in the Electrical Times of June 6 of experiments in factory lighting, reproducing by artificial means the most desirable features of natural lighting. Normal modern practice, based on pre-War experience, dwells on the importance of adequate illumination levels and of limitation of glare. But war-time conditions have greatly accentuated defects which were tolerable under peace conditions of working. In addition, the blacking-out of windows and skylights has usually resulted in conditions such that the psychological effect is of a magnitude creating an entirely new factor. It is unavoidable that operatives are required to work longer hours. It is obviously vital to ensure that any sense of strain is not associated in their minds with factory conditions, which should clearly be designed to conserve both mental and physical reserves. No other factor is more potent psychologically than the lighting installation. Diagrams are given showing the objectionable tunnel effect pro- 